\title{
Management outcome of peroneal nerve injury at knee level: experience of a single military institution
}

\section{Wyniki leczenia uszkodzenia nerwu strzatkowego na wysokości kolana: doświadczenie oddziału szpitala wojskowego}

Ilker Solmaz, Eralp N. Cetinalp, Cüneyt Görsmez, Baki S. Albayrak, Cahit Kural, H. Serdar Kaya, H. Ibrahim Secer, Mehmet Daneyemez, Engin Gonul

Department of Neurosurgery, Gulhane Military Medical Academy, Ankara, Turkey

Neurologia i Neurochirurgia Polska 2011; 45, 5: 461-466

\begin{abstract}
Background and purpose: We investigated the management outcome of common peroneal nerve decompression at the knee level between the years 2005 and 2009 .

Material and methods: Thirty consecutive patients with knee-level peroneal nerve injury who underwent decompression surgery and external neurolysis at our institution were evaluated preoperatively and postoperatively by electrophysiological studies and motor examination (Medical Research Council grading).

Results: Twenty-eight of the cases were male and 2 were female. Mean age was 31.1 for males and 57.5 for females. Physical activity during military training (overstretch/contusion) was the cause of nerve lesion in the majority of the patients $(n=28,93 \%)$. Mean time interval between the diagnosis and the surgery was 5 months. Follow-up time ranged from 3 to 48 months (mean: 14 months). Twenty-nine of 30 (97\%) patients recovered totally or near totally in foot/toe dorsiflexion. Conclusions: Early decompression and neurolysis of the common peroneal nerve $(\mathrm{CPN})$ at knee level after strenuous physical activity offers excellent functional recovery. Additionally, for knee-level CPN injuries, in order to minimize the postoperative scar, pain and delay in wound healing, we strictly advocate short 'lazy S-shaped incision' around the fibular head in supine position unlike the classical extensive opening up to the superior border of the popliteal fossa in prone position.
\end{abstract}

\section{Streszczenie}

Wstęp i cel pracy: Autorzy ocenili wyniki chirurgicznego odbarczenia nerwu strzałkowego wspólnego na wysokości kolana, wykonywanego w latach 2005-2009.

Materiał i metody: Przedoperacyjnej i pooperacyjnej ocenie klinicznej (w skali Medical Research Council) oraz elektrofizjologicznej poddano 30 kolejnych pacjentów z uszkodzeniem nerwu strzałkowego na wysokości kolana, u których wykonano odbarczenie chirurgiczne z zewnętrzną neuroliza.

Wyniki: Wśród leczonych było 28 mężczyzn (średnia wieku: 31,1 roku) i dwie kobiety (średnia wieku: 57,5 roku). U zdecydowanej większości pacjentów $(n=28,93 \%)$ przyczyną uszkodzenia nerwu była aktywność fizyczna w czasie szkolenia wojskowego (nadmierne rozciąnięcie/stłuczenie). Średnia czasu od rozpoznania do operacji wyniosła 5 miesięcy. Obserwacja po zabiegu trwała od 3 do 48 miesięcy (średnia: 14 miesięcy). U 29 na 30 chorych (97\%) uzyskano pełny lub prawie pełny powrót zgięcia grzbietowego stopy/palców.

Wnioski: Wczesne chirurgiczne odbarczenie i neuroliza nerwu strzałkowego wspólnego na wysokości kolana w leczeniu urazu powstałego wskutek nadmiernej aktywności fizycznej daje możliwość znakomitej poprawy czynnościowej. Ponadto w przypadku uszkodzeń nerwu strzałkowego wspólnego na wysokości kolana w celu zminimalizowania blizny pooperacyjnej, nasilenia bólu i opóźnienia w gojeniu się rany pooperacyjnej autorzy usilnie zalecają krótkie cięcie w kształcie wydłużonej

Correspondence address: Baki S. Albayrak, MD, Gulhane Military Medical Academy, 06010 Ankara, Turkey, phone +905323089772 ,

fax+903123045300, e-mail: serdarbaki@gmail.com

Received: 1.10.2010; accepted: 22.03.2011 
Key words: peroneal nerve injury, neurolysis, physical activity, military training, management outcome.

\section{Introduction}

The common peroneal nerve $(\mathrm{CPN})$ is one of the most frequently entrapped nerves in the extremities [1-6]. Entrapment of the nerve mostly occurs on the lateral side of the knee where the nerve traverses the fibular head and runs more superficially. While the deeper and anterior branch of the CPN, namely the deep peroneal nerve (DPN), innervates the muscles of the anterior calf, the superficial branch, the superficial peroneal nerve (SPN), is responsible for the motor and sensory innervation of the muscles of the lateral calf. These two branches run together and are generally entrapped at the same time. Aetiological factors mainly include long-lasting crouching, sitting cross-legged, knee bending, improper leg casts, prosthesis and complications of orthopaedic surgery [6-8]. Loss of motor strength, atrophy, sensorial impairment in the anterior and lateral calf muscles as well as weakness in the dorsiflexion and eversion of foot and toes constitute the main clinical picture of peroneal nerve injury. Diagnosis is generally established by the history, physical examination, and electrophysiological tests. L5 radiculopathy and metabolic sensory-motor neuropathies are other entities to be considered in the differential diagnosis [9].

There are limited reports on the optimum surgical management modality and the timing of surgical intervention for peroneal nerve lesions. In this regard, we believe that our series contributes to the issue of peripheral nerve injury in regard to timing of surgery and surgical approach.

\section{Material and methods}

Between 2005 and 2009, thirty consecutive patients with CPN injury underwent surgical intervention under general anaesthesia at Gulhane Military Medical Academy Hospital. Functional recovery status was evaluated prospectively by Medical Research Council (MRC) grading. Mean follow-up time was 14 months and patients were examined regularly at 3-month intervals and electromyography was repeated at 6 and 12 months after sur- litery „," wokół głowy strzałki u chorego w pozycji leżącej na plecach zamiast klasycznego otwarcia aż do górnej granicy dołu podkolanowego w pozycji leżącej na brzuchu.

Słowa kluczowe: uszkodzenie nerwu strzałkowego, neuroliza, aktywność fizyczna, szkolenie wojskowe, wyniki leczenia.

gery. Twenty-eight of the cases were male and 2 were female. Mean age was 31.1 years for males and 57.5 years for females. While strenuous sport activity and training exercises in the military setting was the only responsible factor in the majority of cases $(n=28,93 \%)$, nerve injury occurred idiopathically as entrapment neuropathy in 2 patients (7\%). These two patients were female and their mean age (57.5 years) was far higher than that of men (31.1 years). Complete loss of foot dorsiflexion was present in 11 patients and ankle jerk was absent in 4 patients. Surgery was performed between 12 days and 48 months (mean: 5 months) after the onset of the symptoms. Decompression and external neurolysis in nontransected nerves were carried out satisfactorily in all patients.

\section{Results}

Table 1 outlines the patients' characteristics and the surgical results. The foot and toe dorsiflexion returned to $5 / 5$ motor strength in 25 (83\%) of the patients. Nine of 11 patients (81\%) with complete loss of foot dorsiflexion preoperatively recovered fully in the follow-up period. While recovery was almost complete (mild paresis $+4 / 5$ strength) in 4 (14\%) patients, we did not observe any improvement in only $1(3 \%)$ patient. Additionally, there was improvement in nerve conduction tests postoperatively in $29(97 \%)$ of the patients. There were no surgery-related complications.

\section{Discussion}

\section{Relevant surgical anatomy}

The CPN originates as the lateral terminal branch of the sciatic nerve at the distal third of the thigh. It travels obliquely across the distal thigh on the lateral aspect of the popliteal fossa, where it has close proximity with the medial border of the biceps femoris muscle. As the nerve goes inferolaterally, it crosses the lateral head of the gastrocnemius muscle and reaches the area just posterior to the fibular head. It curves around the fibular head and 


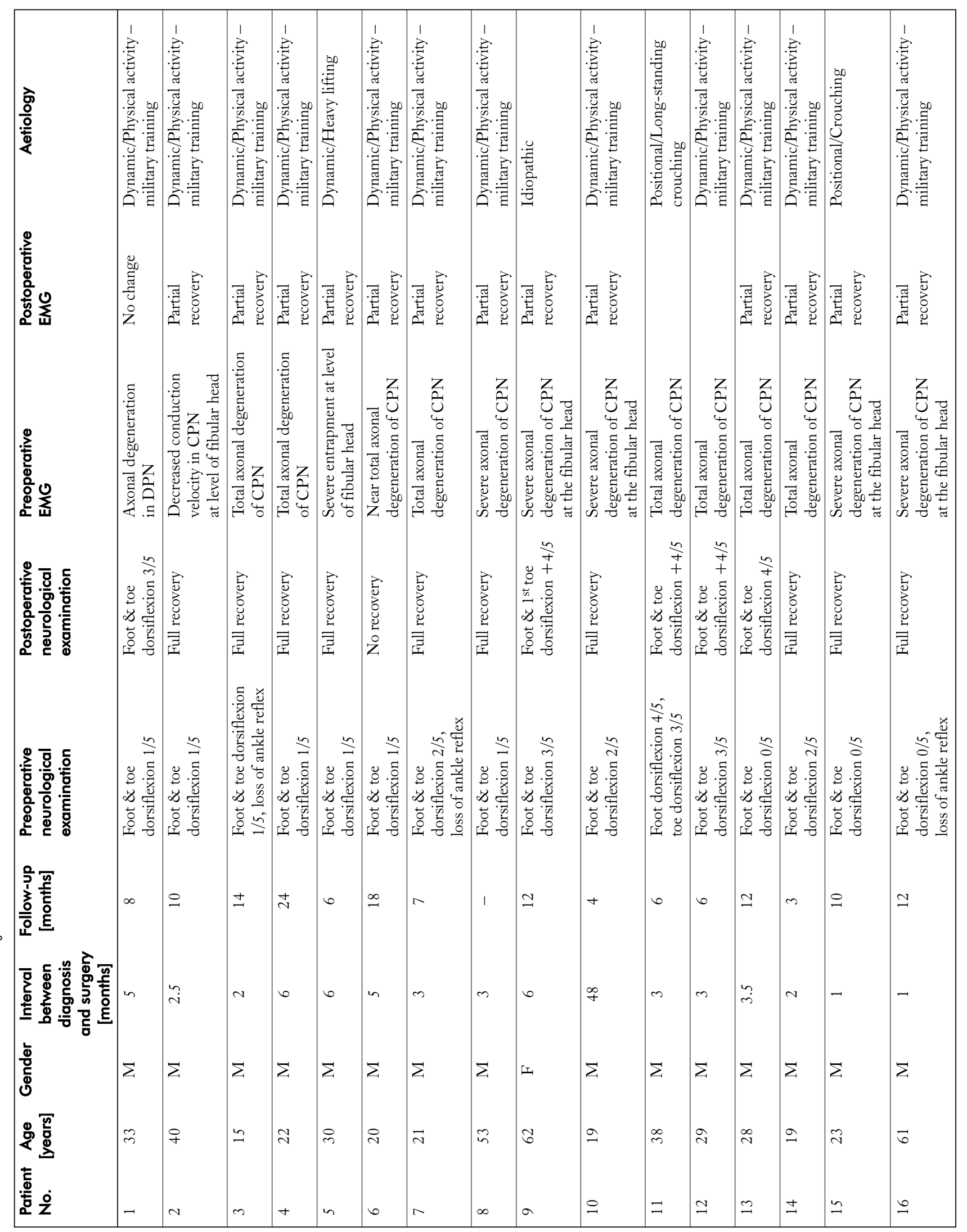




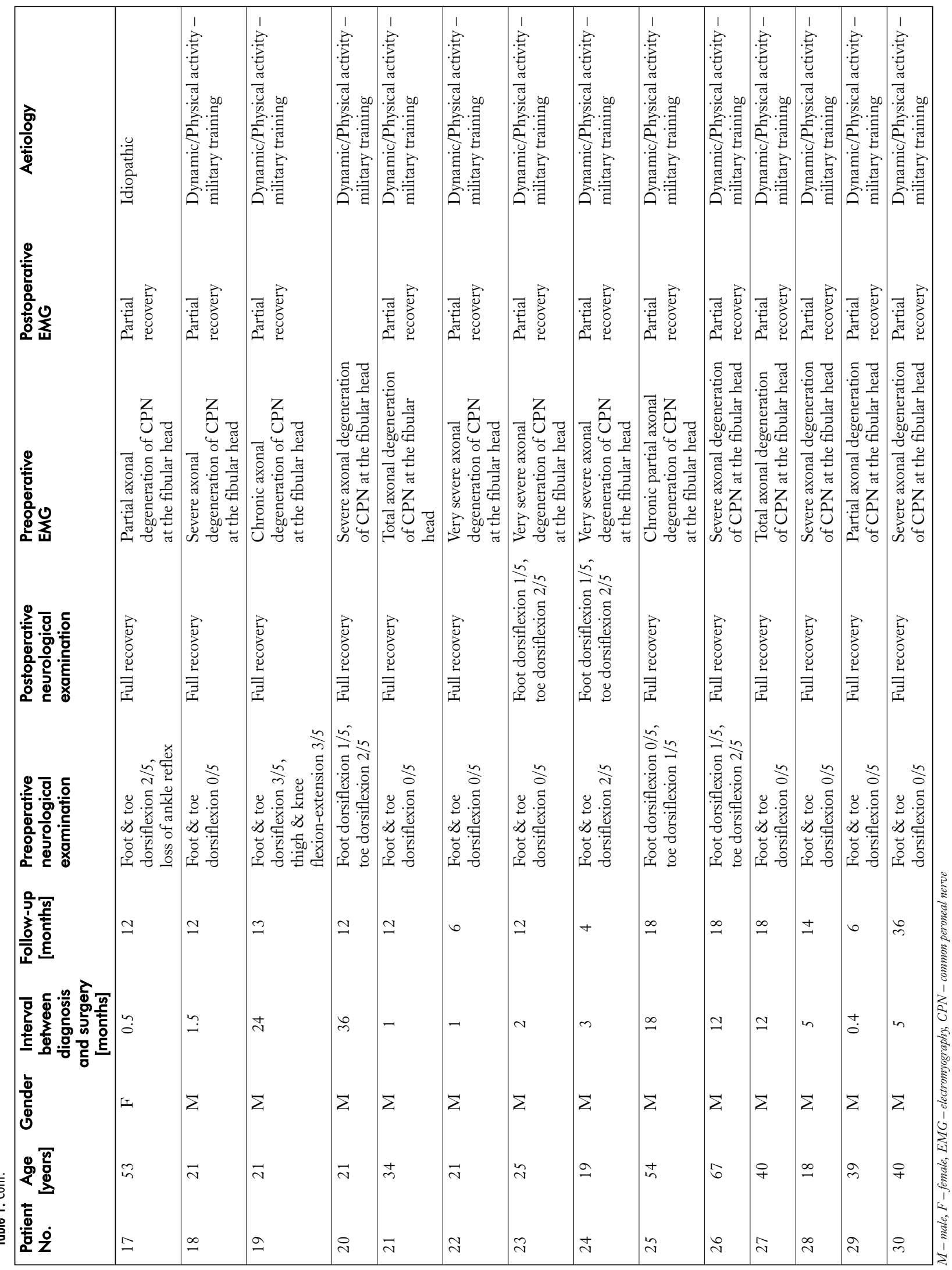


enters a tunnel formed by the two heads of the peroneus longus muscle and the fibular neck. This fibrous tunnel is the site where the CPS is mostly trapped because of the peculiar internal anatomy, subtle blood supply and the complex fascicular composition of the nerve itself resulting in the narrowing of the tunnel $[5,7,10]$.

\section{Surgical technique and the pitfalls}

Patients were positioned supine with the involved knee slightly flexed and supported with paddings (Fig. 1). A 'lazy S-shaped' incision extending between the medial to the short head of the biceps femoris proximally and the fibular neck distally is formed. In our experience, this minimal opening (around $6 \mathrm{~cm}$ ) provided us enough exposure of the CPN in all patients; however, in cases of nerve rupture or gunshot injuries, the incision could be tailored and extended up to the superior border of the popliteal fossa in between the two heads of the biceps femoris muscle so that the CPN could be followed up to the division of the sciatic nerve. The skin is infiltrated with a $1 \%$ lidocaine with epinephrine 1:100,000 solution and then incised. Extreme care should be taken in making the skin incision since the nerve is very superficial around the fibular head. At this step, careful dissection also enables the sparing of the cutaneous sensory branches. After subcutaneous fat tissue is dissected, the CPN should be identified at the proximal posterior fibular head and then be traced around the fibular head down to the fibular neck. The nerve then should be dissected free with a right-angle clamp and then encircled with a Penrose drain or a vessel loop (Fig. 2). Some authors advocate the minimal removal of the posterior proximal fibular head for better exposure and nerve transposition but we do not prefer this modification since bone removal may potentially cause postoperative pain and delay in healing. Once the CPN, deep and superficial branches are identified, the overlying fibrous tunnel composed of nerve fascicles and the fascias in between the heads of the peroneus longus muscle is incised carefully for nerve decompression. Based on our experience, dissecting only the fibrous tissue, and not the peroneus longus muscle or its tendons, is the key to avoid causing postsurgical fibrosis and subsequent functional loss.

\section{Mechanism of injuries in our series}

Patients presented with loss of CPN function including weakness of dorsiflexion of foot and toes. The majority of our patients are young males and their complaints

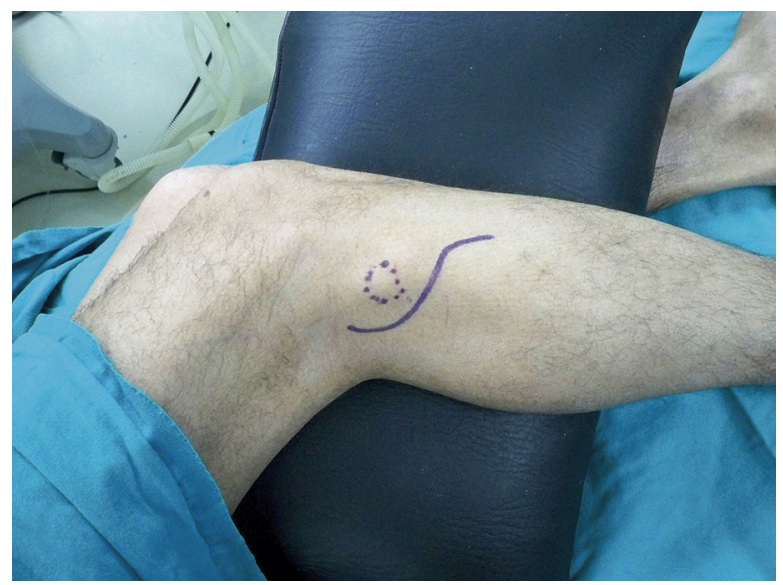

Fig. 1. Surgical position

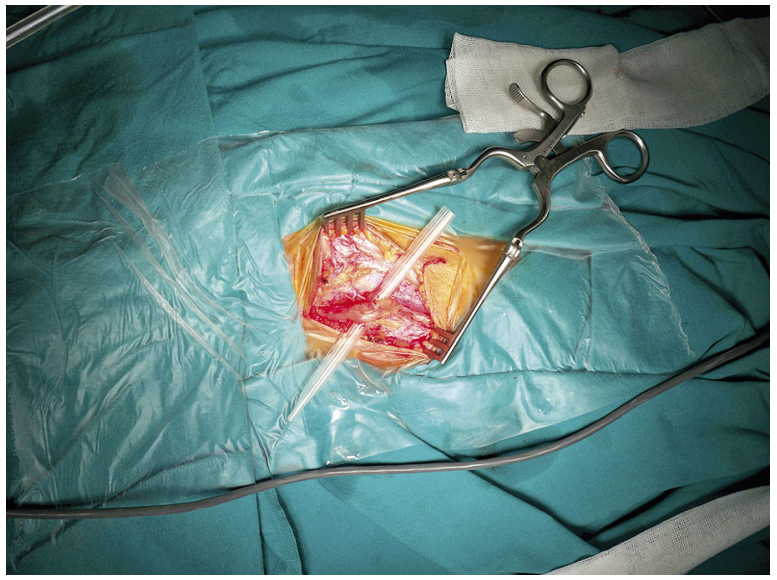

Fig. 2. Exposure of peroneal nerve

generally started after strenuous physical activity following routine military training. Sport or physical activity-related $\mathrm{CPN}$ injuries are generally associated with stretch/contusion and without any obvious fracture or dislocation. In only 2 female patients above 50 years of age was there no history of knee injury, and the mechanism of injury was thought to be entrapment for over years. Electromyography did show partial or complete axonal degeneration in all patients with partial or significant axonal recovery in 29 of 30 patients after neurolysis.

\section{Surgical outcome of CPN injuries in the literature}

In 1940, Platt reported 9 cases with CPN traction injury. Of 9 patients, 4 had an intact non-ruptured peroneal nerve. He operated on 3 of these 4 patients with an intact but overstretched/contused CPN. Of 3 patients, 2 had partial, and 1 had perfect recovery [11]. In 1969, 
Sidey reported on 23 patients with peroneal nerve injury and he concluded that the surgical outcome in patients with long-lasting symptoms was almost equally good as for those having symptoms for shorter durations [12]. Vastamaki et al. reported on 25 patients who had developed CPN injury following knee surgery. Twenty-three patients did show recovery at different grades and the recovery was complete in 15 cases; 4 of them underwent surgery with delay of 1 year or greater [13]. Likewise, Thoma et al. concluded that decompression and neurolysis even after 1-year surgical delay offered good recovery based on the outcome derived from 20 consecutive patients with CPN injuries [6]. In their extensive study, Kim et al. analysed and reported on 318 patients with knee-level peroneal nerve lesions [5]. The authors meticulously classified the aetiologies of the injuries and the surgical outcome in each group. In their series, the best results were obtained after neurolysis and when nerve action potentials were present preoperatively. End-to-end suture anastomosis and shorter nerve grafts less than $6 \mathrm{~cm}$ also resulted in favourable surgical outcome. Kim et al. also recommended immediate surgical repair for sharp lacerations and the repair 2 to 4 weeks after blunt injuries. According to the authors, nerve injuries due to gunshot wounds should be operated on 3 months after injury if there is no obvious recovery. Likewise, there must be an observational period up to a few months before surgical repair of the peroneal nerve due to stretch/contusional injuries in order to avoid unnecessary exploration and neurolysis in case of spontaneous functional recovery.

\section{Conclusions}

1. Early decompression and neurolysis of $\mathrm{CPN}$ at knee level after strenuous physical activity offers excellent functional recovery.

2. Additionally, for knee-level $\mathrm{CPN}$ injuries, in order to minimize the postoperative scar, pain and delay in wound healing, we strictly advocate a short lazy S-shaped incision' around the fibular head in supine position unlike the classical extensive opening up to the superior border of the popliteal fossa in prone position.

\section{References}

1. Maniker A.H. Operative exposures in peripheral nerve surgery. Thieme, New York 2001.

2. Baysefer A., Izci Y., Akay K.M., et al. Surgical outcomes of ulnar nerve lesions in children. A retrospective clinical study. Pediatr Neurosurg 2004; 40: 107-111.

3. Daneyemez M., Solmaz I., Izci Y. Prognostic factors for the surgical management of peripheral nerve lesions. Tohoku J Exp Med 2005; 205: 269-275.

4. Kim D.H., Murovic J.A., Tiel R., et al. Management and outcomes in 353 surgically treated sciatic nerve lesions. Neurosurgery 2009; 101: 8-17.

5. Kim D.H., Murovic J.A., Tiel R.L., et al. Management and outcomes in 318 operative common peroneal nerve lesions at the Louisiana State University Health Sciences Center. Neurosurgery 2004; 54: 1421-1428 [discussion 1428-1429].

6. Platt H. Traction lesions of the external popliteal nerve. Lancet $1940 ; 2: 612$.

7. Secer H.I., Daneyemez M., Tehli O., et al. The clinical, electrophysiologic, and surgical characteristics of peripheral nerve injuries caused by gunshot wounds in adults: a 40-year experience. Surg Neurol 2008; 69: 143-152.

8. Secer H.I., Daneyemez M., Gonul E., et al. Surgical repair of ulnar nerve lesions caused by gunshot and shrapnel: results in 407 lesions. J Neurosurg 2007; 107: 776-783

9. Sidey J.D. Weak ankles: a study of common entrapment neuropathy. Br Med J 1969; 3: 623.

10. Thoma A., Fawcett S., Ginty M., et al. Decompression of the common peroneal nerve: experience with 20 consecutive cases. Plast Reconstr Surg 2001; 107: 1183-1189.

11. Tracy J.A., Engelstad J.K., Dyck P.J. Microvasculitis in diabetic lumbosacral radiculoplexus neuropathy. J Clin Neuromuscul Dis 2009; 11: 44-48.

12. Vastamaki M. Decompression for peroneal nerve entrapment. Acta Orthop Scand 1986; 57: 551.

13. Yildirim S., Gideroğlu K., Aköz T. Peroneal nerve injury caused by fracture of the distal femoral shaft. Plast Reconstr Surg 2003; 111: 511-513.

\section{Disclosure}

The authors report no conflict of interest. 